\title{
KARAKTERISTIK FLAKE UBI JALAR ORANGE DAN UNGU DENGAN PENAMBAHAN MINYAK NABATI (MINYAK SAWIT, MINYAK KELAPA, DAN MARGARIN)
}

\author{
Characteristic of Orange and Purple Sweet Potatoes Flake Added by Vegetable Oils (Palm \\ Oil, Coconut Oil and Margarine)
}

\author{
Avinda Nur Rahmawati ${ }^{1)}$, Maryanto Maryanto ${ }^{1)}$, Nurhayati Nurhayati ${ }^{1) *}$ \\ 1)Jurusan Teknologi Hasil Pertanian, Fakultas Teknologi Pertanian, Universitas Jember \\ Jalan Kalimantan No. 37 Kampus Tegal Boto, Jember, 68121 \\ *Korespondensi Penulis: nurhayati.ftp@unej.ac.id
}

\begin{abstract}
Sweet potato flake is ready-to-eat foods comsumed by the adding a milk. Lipid or oil in the flake can change the crunchy and texture. Oil was added to fungtions as the stabilisator, lubricant and to improved crispness of flake. The aims of this study was to evaluate of physical and sensory characteristic of flake made from orange and purple sweet potatoes with addition the vegetable oils. This study used Complete Random Design (CRD) with two factors and two replications. The A factor was type of sweet potatoes, i.e. orange sweet potato (A1) and purple sweet potato (A2). The $B$ factors (B) were type of oils; palm oil (B1), coconut oil (B2) and margarine (B3). The results showed that the rehydrations flake of orange and purple sweet potatoes with additions of variation oil type ranged from $(58,13$ - 85,61\%,); hygroscopicity ranged (6,93 - 8,86\%); water content ranged from (3,57 $6,47 \%)$. The highest favorite value of color on orange sweet potato flake with addition margarine $(5,42)$, while purple sweet potato flake with addition palm oil has the lowest favorite value $(3,46)$. The aroma value of orange and purple sweet potatoes flake with the addition coconut oil has the highest $(5,15)$ and $(5,35)$ than palm oil and margarine. Preference taste of orange and purple sweet potatoes flakes was the highest if additions of coconut oil, i.e. very like (score 5,12). Crispness preference was preferred from orange sweet potato flake with coconut oil additions (4,96). Favorite taste was preferred on purple sweet potato flake with coconut oil addition $(5,38)$.
\end{abstract}

Keywords: coconut oil, flake, preference test, sweet potato, vegetable oil

\section{PENDAHULUAN}

Flake merupakan produk pangan siap saji yang berbentuk pipih yang dikonsumsi dengan penambahan susu. Selain itu,flake juga dapat dikonsumsi sebagai makanan ringan. Saat ini diversifikasi formula bahan yang digunakan pada pembuatan flake banyak dilakukan. Hal tersebut karena tekstur yang renyah pada flake menjadi penting untuk diperhatikan. Upaya perbaikan tekstur renyah flake tidak hanya ditentukan dari komponen mayor seperti total pati dan protein, melainkan juga komponen minor salah satunya yakni lemak. Beberapa komponen minor seperti emulsifier, lemak dan minyak, gula, garam vitamin dan mineral dapat memberikan pengaruh pada karakteritstik produk
(Hsieh et al., 1990). Adanya lemak dan minyak dalam pembuatan produk ekstrudat seperti flake berperan sebagai stabilisator. Hal tersebut karena adanya lemak maupun minyak dapat menurunkan viskositas adonan, mencegah tekstur yang liat dan membentuk adonan yang kalis. Ubi jalar yang memiliki kadar lemak yang sangat rendah hanya sebesar $0,81 \%$. Dengan demikian, salah satu upaya yang dapat dilakukan untuk memenuhi sumber lemak ataupun minyak penambahan minyak nabati seperti minyak sawit, minyak kelapa dan margarin. Adanya penambahan minyak juga diharapkan dapat memperbaiki karakteristik flake. Hal tersebut karena sifat fisik dan kimia minyak nabati yang ditambahkan berbeda. 
Oleh karena itu pentingnya dilakukan penelitian penambahan variasi jenis minyak pada pembuatan flake ubi jalar orange dan ungu untuk mengetahui karakteristik fisik dan sensosris flake ubi jalar orange dan ungu dengan penambahan variasi jenis minyak.

\section{METODE PENELITIAN}

\section{Alat dan Bahan}

Alat utama pembuatan flake ubi jalar yaitu cetakan tradisional, sedangkan alat untuk analisis meliputi botol timbang, mortar, penjepit, oven, loyang, deksikator neraca analitis dan alat-alat gelas. Bahan baku yang digunakan pada pembuatan flake yaitu tepung ubi jalar orange, tepung ubi jalar ungu yang diperoleh dari Dr. Nurhayati, S.TP., M.Si. selain itu juga diperlukan tepung beras putih, gula, kuning telur, santan kara, SKM dan minyak nabati yaitu minyak sawit, minyak kelapa dan margarin. Bahan untuk analisis antara lain aquades, alumunium foil, tisu, dan label.

\section{Tahapan Penelitian}

\section{Pembuatan Flake Ubi Jalar}

Pembuatan flake diawali dengan pencampuran tepung ubi jalar orange dan ungu masing-masing sebanyak $100 \mathrm{~g}$, tepung beras $150 \mathrm{~g}$, kuning telur $15 \mathrm{~g}$ dan santan kara 15 g, susu kental manis (SKM) $25 \mathrm{~g}$, telah dilarutkan dengan air sebanyak $150 \mathrm{~mL}$ bertujuan untuk mempercepat homogenisasi pada adonan. Selanjutnya adonan yang homogen dilakukan penambahan minyak sayur sesuai perlakuan yakni minyak sawit, minyak kelapa dan margarin masing-masing sebanyak 25 g sampai terbentuk adonan yang kalis dan homogen. Selanjutnya dilakukan pemanggangan pada suhu $100^{\circ} \mathrm{C}$ selama 3 menit menggunakan alat pencetak tradisional. Setelah itu flake dilakukan pemotongan sebesar $\pm 1 \times 2$ $\mathrm{cm}^{2}$ dalam keadaan hangat. Pemotongan flake setelah pemanggangan harus segera dilakukan secara langsung, karena adanya retrogradasi tekstur flake menjadi keras cepat terbentuk seiring semakin turunnya suhu sehingga pemotongan menjadi terhambat. Kemudian dilakukan sortasi untuk memisahkan antara flake sesuai dengan ukuran yang telah ditentukan dari remahan, dan diperoleh flake target.

\section{Rancangan Percobaan}

Penelitian ini menggunakan metode Rancangan Acak Lengkap (RAL) 2 faktor dan 2 ulangan. Faktor pertama jenis ubi (A) terdiri dari Ubi jalar orange (A1) dan ubi ungu (A2). Jenis minyak (B) terdiri dari minyak sawit (B1), minyak kelapa (B2) dan margarin (B3).

\section{Analisis Mutu Flake}

Flake ubi jalar yang dilakukan pengujian sifat fisik meliputi daya rehidrasi (Tamtarini dan Yuwanti, 2005), higroskopisitas (Rosiani et al., 2015) dan kadar air metode thermogravimetri (Sudarmadji et al., 1997). Uji kesukaan sensoris meliputi paramater warna, aroma, rasa, tekstur, tekstur flake dalam seduhan susu dan keseluruhan metode hedonic skoring (Meilgaard et al., 1999). Uji sensoris kepada 26 panelis tidak terlatih yang terdiri dari laki-laki dan perempuan.

\section{HASIL DAN PEMBAHASAN}

\section{Daya Rehidrasi Flake Ubi Jalar Orange dan Ungu}

Daya rehidrasi flake menunjukkan bahwa jenis ubi dan jenis minyak berpengaruh nyata terhadap flake ubi yang dihasilkan. Daya rehidrasi flake ubi orange dan ungu ditunjukkan Tabel 1.

Daya rehidrasi dipengaruhi oleh daya kembang bahan. Flake ubi orange dengan margarin memiliki daya rehidrasi lebih tinggi $85,61 \%$ daripada flake ubi orange dengan minyak sawit dan minyak kelapa yakni $76,89 \%$ dan $74,22 \%$. Hal itu dipengaruhi oleh kadar amilosa dalam bahan. Kadar amilosa tepung ubi jalar 
orange 23,42\% (Tsalisati et al., 2016), sedangkan tepung ubi ungu $24,79 \%$ (Nindyarani et al., 2011). Semakin rendah kadar amilosa, semakin tinggi daya kembang bahan. Hal tersebut disebabkan karena molekul amilopektin memiliki kemampuan mengikat air yang lebih tinggi daripada amilosa yang cenderung membentuk ikatan dengan lemak.

Tabel 1. Karakteristik fisik flake ubi orange dan ungu

\begin{tabular}{cccc}
\hline Perlakuan & $\begin{array}{c}\text { Daya } \\
\text { rehdrasi } \\
(\%)\end{array}$ & $\begin{array}{c}\text { Higroskopisitas } \\
(\%)\end{array}$ & $\begin{array}{c}\text { Kadar } \\
\text { air } \\
(\% \mathrm{bk})\end{array}$ \\
\hline A1B1 & $72,70 \mathrm{~d}$ & 8,86 & 5,12 \\
A1B2 & $76,89 \mathrm{e}$ & 7,03 & 5,05 \\
A1B3 & $85,61 \mathrm{f}$ & 8,22 & 3,57 \\
A2B1 & $58,13 \mathrm{a}$ & 6,93 & 6,47 \\
A2B2 & $68,67 \mathrm{c}$ & 8,30 & 4,06 \\
A2B3 & $63,60 \mathrm{~b}$ & 8,74 & 4,82 \\
\hline
\end{tabular}

Keterangan: $\mathrm{bk}=$ berat kering

Seiring dengan adanya komponen lemak padat dalam margarin yang cukup tinggi. Margarin merupakan produk pangan semi padat dengan sistem emulsi air dalam minyak (w/o) yang terdiri $80 \%$ lemak dan sisanya air (Ketaren, 2008). Selain itu margarin juga dipengaruhi oleh bentuk kristal margarin yang lebih kasar dari pada minyak cair. Dimana ukuran kristal sangat dipengaruhi oleh komponen asam lemak jenuh dan lemak tidak jenuh dalam lemak. Menurut Potter dan Hitchkiss (1995), minyak cair memiliki bentuk kristal-kristal lemak yang lebih halus, sedangkan margarin memiliki sistem emulsi yang lebih stabil. Pati yang mengalami gelatinisasi memerlukan komposisi margarin yang lebih tinggi untuk menghasilkan karakteristik flake lebih baik. Akan tetapi keberadaan lemak cair dapat menghambat pengembangan granula pati.

Mamat dan Hill (2012) melaporkan bahwa kristal lemak yang terdapat pada lemak padat selama pemasakkan membentuk rongga udara yang lebih heterogen dan tidak terdistribusi merata daripada minyak cair pada minyak sawit dan fraksi semi padat. Distribusi kristal lemak yang homogen ketika gelatinisasi pati akan menghambat pengembangan granula dan menguapnya molekul air, sehingga mengakibatkan jumlah rongga udara semakin rendah. Semakin rendah rongga terbentuk maka semakin rendah air terserap, menunjukkan bahwa semakin rendah daya rehidrasi flake begitu pula sebaliknya.

\section{Higroskopisitas Flake Ubi Jalar Orange dan Ungu}

Higroskopis merupakan kemampuan suatu bahan yang mudah menyerap uap air dari lingkungan (Lindriati dan Maryanto, 2016). Hasil penelitian ini menunjukkan bahwa jenis ubi dan jenis minyak tidak berpengaruh nyata pada higroskopisitas flake. Higroskospsitas tertinggi sebesar 8,86\% pada flake ubi jalar orange dengan minyak sawit, sedangkan terendah pada flake ubi orange dengan margarin yakni 6,93\%. Menurut Setyowati (2010) melaporkan bahwa volume pengembangan yang lebih besar memiliki higroskopisitas semakin tinggi pula. Namun adanya lemak dapat menghambat terserapnya uap air dari udara lingkungan sekitar.

\section{Kadar Air Flake Ubi Jalar Orange dan Ungu}

Tabel 1 menunjukkan bahwa flake ubi jalar ungu dengan penambahan minyak sawit memiliki kadar air tertinggi $6,47 \%$, sedangkan flake ubi orange dengan penambahan margarin paling rendah sebasar 3,57\%. Kadar air flake yang dihasilkan dipengaruhi oleh kadar air awal bahan. Adanya perlakuan jenis ubi, dengan penambahan variasi minyak nabati yang sama, kadar air flake ubi ungu lebih tinggi daripada flake ubi orange. Hal itu karena kadar air tepung ubi ungu lebih tinggi daripada tepung ubi orange, sehingga semakin banyak molekul air yang diuapkan dari bahan. Menurut Susilawati dan Medikasari (2008) menyatakan bahwa 
kadar air tepung ubi jalar orange dan ungu masing-masing yakni $6,77 \%$ dan $7,28 \%$. Namun, flake ubi ungu dengan penambahan minyak kelapa cenderung memiliki kadar air yang lebih rendah yakni $4,06 \%$ daripada flake ubi orange sebesar $5,05 \%$ oleh kadar protein ubi orange dan kandungan amilosa yang lebih rendah daripada ubi ungu. Tepung ubi orange memiliki kadar protein lebih tinggi yakni $4,41 \%$ daripada tepung ubi ungu sebesar 2,79\% (Susilawati dan Medikasari, 2008).

\section{Sifat Sensoris Flake Ubi Jalar Orange dan Ungu}

Warna Flake Ubi Jalar

Warna merupakan salah satu atribut sensoris yang penting menggambarkan kenampakan suatu produk (Sianturi dan Marliyati, 2014). Nilai kesukaan panelis terhadap warna flake ubi jalar ungu dan orange semua perlakuan berkisar antara 3,46 sampai 5,42 (agak tidak suka - agak suka). Warna flake ubi jalar ungu cenderung coklat, sedangkan flake ubi jalar orange berwarna kuning kecoklatan.

Adanya perlakuan variasi minyak yang ditambahkan menunjukkan bahwa penambahan margarin pada flake ubi orange paling disukai panelis 5,42 (agak suka) daripada flake ubi ungu dengan penambahan margarin 3,46 (agak tidak suka). Secara alami margarin lebih berwarna kuning berasal dari pigmen betakaroten (Rukmana, 1997). Adanya pemanggangan flake akan menjadi berwarna lebih gelap karena terjadinya reaksi maillard. Menurut Malinda et al. (2013) bahwa warna flake yang semakin gelap dapat mengurangi kesukaan panelis. Oleh karena itu penambahan margarin pada flake ubi orange lebih disukai daripada flake ubi ungu.

\section{Aroma Flake Ubi Jalar}

Aroma merupakan bau dari suatu produk makanan dimana senyawa volatil akan terhirup ke dalam rongga hidung dan ditangkap oleh sistem olfaktori (Kemp et al., 2009). Aroma berperan penting dalam industri pangan untuk meningkatkan daya tarik produk pangan tersebut. Nilai kesukaan aroma flake oleh panelis berkisar 4,54 sampai 5,35 (netral - agak suka). Aroma tepung ubi jalar pada flake tidak begitu mencolok dan cenderung didominasi oleh aroma minyak. Panelis lebih menyukai aroma flake ubi jalar orange dan ungu dengan penambahan minyak kelapa yakni 5,12, dan 5,35. Namun panelis kurang menyukai flake ubi jalar orange dan ungu dengan penambahan minyak sawit dengan nilai kesukaan paling rendah yakni 4,81 dan 4,54. Hal itu disebabkan karena panelis menilai aroma minyak kelapa dan margarin lebih harum daripada aroma minyak sawit. Minyak kelapa beraroma khas dan gurih yang berasal dari yakni senyawa nonyl methylketon (Ketaren, 2008). Senyawa $\delta$ dekalakton, asam decanoik dan $\delta$ oktalakton paling banyak terdapat pada margarin yang menghasilkan aroma harum (Demirkol et al., 2016).

\section{Rasa Flake Ubi Jalar}

Rasa adalah salah satu parameter penting dalam cita rasa pangan yang dapat mempengaruhi penerimaan masyarakat terhadap suatu produk. Nilai kesukaan oleh panelis pada semua variasi perlakuan flake ubi jalar berkisar antara 4,42 sampai 5,15 (netral-agak manis). Tabel 2 menunjukkan bahwa panelis cenderung menyukai rasa flake ubi jalar orange dengan penambahan margarin yang dibuktikkan oleh nilai kesukaan paling tinggi yaitu 5,15 (agak manis). Nilai kesukaan cukup tinggi juga terjadi pada flake ubi ungu dengan penambahan minyak kelapa 5,12 (agak manis). Hal tersebut disebabkan karena minyak kelapa juga dapat memberikan rasa gurih yang khas pada flake. Namun penambahan minyak sawit pada flake ubi orange dan ungu nilai kesukaan paling rendah berturut-turut sebesar 4,65 dan 4,42 (netral). 
Tabel 2. Karakteristik sensoris flake ubi orange dan ungu

\begin{tabular}{lcccccc}
\hline Perlakuan & A1B1 & A1B2 & A1B3 & A2B1 & A2B2 & A2B3 \\
\hline Warna & 5,30 & 5,38 & 5,42 & 5,23 & 5,30 & 5,19 \\
Aroma & 4,81 & 5,12 & 4,42 & 4,54 & 5,35 & 4,85 \\
Rasa & 4,65 & 5,12 & 5,15 & 4,42 & 5,12 & 4,81 \\
Tekstur & 4,77 & 4,65 & 4,73 & 4,77 & 4,96 & 4,88 \\
Tekstur seduhan & 4,69 & 4,73 & 4,77 & 4,77 & 5,04 & 5,04 \\
Overall & 4,88 & 5,00 & 4,81 & 5,08 & 5,38 & 5,31 \\
\hline
\end{tabular}

Keterangan: A1B1: ubi jalar orange dengan penambahan minyak sawit; A1B2: ubi jalar orange dengan penambahan minyak kelapa; A1B3: ubi jalar orange dengan penambahan margarin; A2B1: ubi jalar ungu dengan penambahan minyak sawit; A2B2: ubi jalar ungu dengan penambahan minyak kelapa; A2B3: ubi jalar ungu dengan penambahan margarin

\section{Tekstur Flake Ubi Jalar}

Tekstur merupakan sensasi tekanan yang dapat dirasakan dengan mulut melalui gigitan dan kunyahan ataupun melalui perabaan dengan jari (Febrianto et al., 2014). Nilai kesukaan rata-rata tekstur flake ubi orange dan ungu memiliki selisih yang tidak berbeda jauh antar perlakuan sebesar 4,65 - 4,96 (netral). Flake ubi jalar ungu dengan penambahan minyak kelapa memiliki nilai kesukaan tekstur tertinggi 4,96 (netral). Panelis menilai bahwa tekstur flake yang semakin kompak dan tidak mudah rapuh lebih disukai.

Hal tersebut dipengaruhi oleh komponen asam lemak dari minyak dan kadar pati ubi jalar. Ikatan komplek antara amilosa-lemak dapat meningkatkan tekstur kompak. Menurut Purnamasari dan Putri (2015) bahwa semakin mudah patah flake maka akan semakin renyah. Serta semakin tinggi nilai kekerasan produk cenderung memiliki tekstur relatif keras dan kurang renyah (Novia et al., 2014).

\section{Tekstur Flake Ubi Jalar dalam Seduhan Susu}

Nilai kesukaan tekstur seduhan dalam susu flake ubi jalar orange dan ungu berkisar antara 4,69 sampai 5,04 (agak tidak renyah - agak renyah). Flake ubi ungu memiliki nilai kesukaan tekstur seduhan dalam susu tertinggi dengan penambahan minyak kelapa dan margarin yakni 5,04. Panelis lebih menyukai tekstur flake yang masih kompak dan tidak mudah rapuh ketika diseduh dengan tingkat penyerapan susu yang cukup tinggi. Namun penambahan minyak sawit tekstur seduhan flake ubi cenderung tidak disukai panelis dengan nilai kesukaan paling rendah. Hal tersebut karena ketika flake dilakukan penyeduhan cenderung tidak mudah menyerap susu, sehingga diperoleh tekstur seduhan yang masih terlalu keras dan padat. Tekstur flake yang dikehendaki yakni renyah dan memiliki kerenyahan dalam susu yang cukup baik (Purnamasari dan Putri, 2015).

\section{Nilai Keseluruhan Flake Ubi Jalar}

Penilaian keseluruhan produk pangan menjadi salah satu parameter penting yang menggambarkan tingkat penerimaan dan kesukaan oleh konsumen (Aini, 2004). Nilai rata-rata kesukaan keseluruhan flake ubi orange dan ungu berkisar antara 4,81 sampai 5,38 (netral agak suka). Flake ubi ungu dengan penambahan minyak kelapa paling disukai panelis yang dibuktikan dengan nilai kesukaan tertinggi 5,38 (agak suka), sedangkan nilai kesukaan terendah 4,81 (netral) pada flake ubi orange dengan penambahan minyak sawit. Secara keseluruhan panelis lebih menyukai flake 
ubi dengan penambahan minyak kelapa daripada minyak sawit dan margarin.

\section{KESIMPULAN}

Karakteristik fisik flake ubi orange dan ungu dengan penambahan variasi jenis minyak berpengaruh nyata pada daya rehidrasi, tidak berpengaruh nyata pada higroskopisitas dan kadar air. Flake ubi orange dengan penambahan margarin memiliki daya rehidrasi paling tinggi $(85,61 \%)$ dengan kadar air terendah $(3,57 \%)$. Hasil uji sensoris diperoleh adanya perlakuan jenis minyak penambahan margarin memiliki nilai kesukaan tertinggi pada parameter warna, rasa dan tesktur seduhan flake. Penambahan minyak kelapa memiliki nilai kesukaan tertinggi pada parameter aroma, tekstur, tekstur seduhan dan keseluruhan. Panelis paling menyukai flake ubi ungu dengan penambahan minyak kelapa. Flake tersebut memiliki nilai kesukaan tertinggi pada aroma, kerenyahan, tekstur seduhan dalam susu dan keseluruhan.

\section{DAFTAR PUSTAKA}

Aini, N. 2004. "Pengolahan Tepung Ubi Jalar dan Produk-Produknya untuk Pemberdayaan Ekonomi Masyarakat Pedesaan". Tesis, Sekolah Pasca Sarjana/S3. IPB. Bogor.

Demirkol, A., Guneser, O., and Yuceer, Y.K. 2016. Volatile compounds, chemical and sensory properties of butters sold in Çanakkale. Journal of Agricultural Science, 22: 99-108.

Febrianto, A., Basito, dan Anam, C. 2014. Kajian karakteristik fisikokimia dan sensoris tortilla corn chips dengan variasi larutan alkali pada proses nikstamalisasi jagung. Jurnal Teknosains Pangan, 3 (3): 22-34.

Ketaren, S. 2008. Minyak dan Lemak Pangan. UI Press, Jakarta.
Hsieh, F., Peng, I.C., dan Huff, H.E. 1990. Effext of salt and sugar screw speed on processing and product variabels of corn meal extruded with a twin-screw extruder. Journal of Food Scieince, 55 (1): 224-227.

Kemp, E., Hollowood, T., dan Hort, J. 2009. Sensory Evaluation: A Practical Handbook. Wiley-Blackwell, United Kingdom.

Ketaren, S. 2008. Minyak dan Lemak Pangan. UI Press, Jakarta.

Lindriati, T., dan Maryanto. 2016. Aktivitas air, kurva sorpsi isothermis serta perkiraan umur simpan flake ubi kayu dengan variasi penambahan koro pedang. Jurnal Agroteknologi, 10 (2): 129-136.

Malinda, A.P., Katri, A.R.B., Rachmawanti A, D., dan Riyadi, P.N.H. 2013. Kajian penambahan tepung millet dan tepung ubi jalar ungu (Ipomea batatas L.) sebagai substitusi tepung terigu pada pembuatan flake. Jurnal Teknosains Pangan, 2 (1): 39-48.

Mamat, H., dan Hill, S.E. 2012. Effect of fat types on the structural and textural properties of dough and semi-sweet biscuit. Journal of Food Science and Technology, 51 (9): 1998-2005.

Meilgaard, M.C., Giville, G.V., and Carr, B.T. 1999. Sensory Evaluation of Techniques (3rd ed.). Boca Raton, FL: CRC Press. http://dx.doi.org/10.1201/97814398322 71.

Nindyarani, A.K., Sutardi, dan Suparmo. 2011. Karakteristik kimia, fisik dan inderawi ubi jalar ungu (Ipomoea batatas P.) dan produk olahannya. Jurnal Agritech, 31 (4): 273-280.

Novia, R., Amanto, B.S., dan Prsetiangga, D. 2014. Formulasi dan evaluasi sifat sensoris dan fisikokimia produk flakes komposit berbahan dasar tepung tapioka, tepung kacang merah (Phaseolus vulgaris L.) dan tepung konjac. Jurnal Teknosains Pangan, 1 (3): 63-73. 
Nurhayati, N., Ruriani, E., dan Maryanto. 2016. Alih teknologi produksi pangan darurat berbahan ubi bagi posdaya Desa Mayangan Kecamatan Gumukmas Jember. Prosiding Seminar APTA.26-27 Oktober 2016. Teknologi Hasil Pertanian FTP UNEJ, pp: 151-156.

Potter, N.N., and Hotchkiss, J.H. 1995. Food Science (5th ed.). Springer, New York.

Purnamasari, I.K., dan Putri, W.D. 2015. Pengaruh penambahan tepung labu kuning dan natrium bikarbonat terhadap karakteristik flake. Jurnal Pangan dan Agroindustri, 3 (4): 1375-1385.

Rosiani, N., Basito, dan Widiowati. 2015. Kajian karaketristik sensori fisik kimia dan kimia kerupuk fortifikasi daging lidah buaya (Aloe vera) metode pemanggangan menggunakan microwave. Jurnal Teknologi Hasil Pertanian, 8 (2): 84-98.

Rukmana. 1997. Ubi Jalar: Budidaya dan Pasca Panen. Kanisius, Yogyakarta.

Setyowati, A. 2010. Penambahan natrium tripolifosfat dan CMC (carboxy methyl cellulose) pada pembuatan karak. Jurnal AgriSains, 1 (1): 40-49.

Sudarmadji, S., Haryono, B., dan Suhardi. 1997. Prosedur Analisa untuk Bahan Makanan dan Pertanian. Edisi Keempat. Liberty, Yogyakarta.

Susilawati dan Medikasari. 2008. Kajian Formulasi Tepung Terigu dan Berbagai Jenis Tepung Ubi Jalar sebagai Bahan Dasar Pembuatan Biskuit Non-Flaky Crackers. Prosiding Seminar Nasional Sains dan Teknologi II. Universitas Lanpung. 17-18 November 2008, pp: 150-169.

Tamtarini dan Yuwanti, S. 2005. Pengaruh penambahan koro-koroan terhadap karakteristik sifat fisik dan sensoris. Jurnal Teknologi Hasil Pertanian, 6 (3): 187-192.
Tsalisati, I.I., Ishartani, D., dan Kawiji. 2016. Kajian kimia, fungsional tepung ubi jalar orange (Ipomea batatas L.) varietas beta 2 dengan pengaruh perlakuan pengupasan umbi. Jurnal Teknosains Pangan, 5 (2): 19-27. 